\title{
Pyrolysis of Water Hyacinth [Eichhornia crassipes (Mart.) Solms] for Liquid Smoke Production
}

\author{
Rita Dwi Ratnani ${ }^{1, *}$, Hadiyanto Hadiyanto ${ }^{2}$, Widiyanto Widiyanto ${ }^{3}$, and Maizirwan $\mathrm{Mel}^{4}$ \\ ${ }^{1}$ Department of Chemical Engineering, Wahid Hasyim University, Jl. Menoreh Tengah X/22 \\ Sampangan, Semarang 50236, Indonesia \\ ${ }^{2}$ Department of Chemical Engineering, Diponegoro University, Jl. Prof. Sudarto No.13, Tembalang, \\ Kec. Tembalang, Semarang 50275, Indonesia \\ ${ }^{3}$ Department of Animal Sains, Diponegoro University, J1. Prof. Sudarto No.13, Tembalang, Kec. \\ Tembalang, Semarang 50275, Indonesia \\ ${ }^{4}$ Department of Biotechnology Engineering, Kulliyyah of Engineering, International Islamic \\ University Malaysia, P.O. Box 10, 50728 Kuala Lumpur, Malaysia
}

\begin{abstract}
This research aimed to determine the chemical composition of Rawapening, Semarang District, Indonesia water hyacinth and to study the effect of pyrolysis time on the volume of liquid smoke products. The water hyacinth was cut into pieces with a size of about $2 \mathrm{~cm}$ to $3 \mathrm{~cm}$, and placed in pyrolisator. A total of $700 \mathrm{~g}$ of water hyacinth sample was fed into the pyrolysis. The product was observed for its content of hemicellulose, cellulose and lignin. The pyrolysis was carried out at a temperature of $117{ }^{\circ} \mathrm{C}, 400{ }^{\circ} \mathrm{C}$ and $683{ }^{\circ} \mathrm{C}$. The results showed that water hyacinth contains hemicellulose $36 \%$ d.b, cellulose $21 \%$ d.b and lignin $7 \%$ d.b which it potential to be a raw material for liquid smoke production. The effect of temperature was significant on liquid smoke products. It was proven that the higher the pyrolysis temperature, the greater the liquid smoke produced. The liquid smoke was obtained for $0.2 \mathrm{~mL}$ per $100 \mathrm{~g}$, $12.3 \mathrm{~mL}$ per $100 \mathrm{~g}$ and $16.3 \mathrm{~mL}$ per $100 \mathrm{~g}$ dried biomass water hyacinth at a temperature of $117^{\circ} \mathrm{C}, 400{ }^{\circ} \mathrm{C}$ and $683{ }^{\circ} \mathrm{C}$, respectively.
\end{abstract}

Keywords: Biomass, lignocellulose, renewable energy, waste to energy

\section{Introduction}

Environmental sustainability around Rawa Pening, Semarang District, Indonesia has changed due to the density of water hyacinth weeds [Eichhornia crassipes (Mart.) Solms]. The growth of water hyacinth is rapid due to eutrophication. Eutrophication is the presence of excess nutrients in the form of nitrate and phosphate which are sourced from agricultural activities, fisheries, settlements, and livestock from the land around the lake. This is the factor made water hyacinth grew quickly and short time to multiply [1]. To control the growth water hyacinth is by utilizing in another product i.e. for liquid smoke as it contains high cellulose.

\footnotetext{
*Corresponding author: ritadwiratnani@unwahas.ac.id
} 
The pyrolysis is used for converting this biomass to liquid smoke. Biomass pyrolysis is usually carried out at temperatures above $150{ }^{\circ} \mathrm{C}$. Pyrolysis is divided into two based on the level of the process, i.e. primary and secondary. Primary pyrolysis takes place at temperatures less than $600{ }^{\circ} \mathrm{C}$. The main result is carbon or charcoal. Primary pyrolysis is further divided into two namely fast and slow primary. Slow primary pyrolysis occurs at $150{ }^{\circ} \mathrm{C}$ to $300{ }^{\circ} \mathrm{C}$ heating. The results slow primary pyrolysis are carbon, water, carbon monoxide and carbon dioxide. Rapid primary pyrolysis that occurs at temperatures over $300{ }^{\circ} \mathrm{C}$ will produce gas, carbon and steam [2].

Subsequent pyrolysis is pyrolysis that occurs at temperatures above $600{ }^{\circ} \mathrm{C}$ and at this temperature, the result is carbon monoxide, hydrogen, hydrocarbons and tar around $1 \%$ to $6 \%[3,4]$.

Decomposition reaction of biomass undergoing pyrolysis will produce as much as $50 \mathrm{~g}$ to $70 \mathrm{~g}$ of steam. The general reaction is as Formula (1):

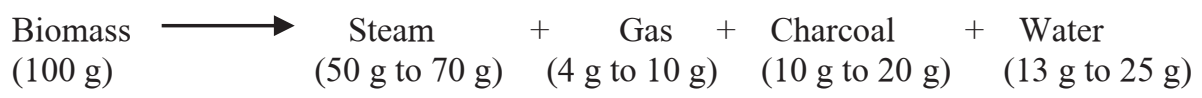

The purpose of this study was to determine the chemical composition of Rawapening's water hyacinth and to study the effect of pyrolysis time on the volume of liquid smoke products.

\section{Materials and methods}

\subsection{Material}

The materials used water hyacinth, distilled water, Phenolphthalein (PP) indicator, $0.1 \mathrm{~N}$ $\mathrm{NaOH}, 2 \% \mathrm{Na}_{2} \mathrm{~S}_{2} \mathrm{O}_{3}$, follicular ciocalteu, 2,4-dinitrophenyl hydrazine, concentrated $\mathrm{HCl}$, $\mathrm{KOH} 1 \mathrm{~N}$.

\subsection{Equipment}

The experiment was carried in a pyrolysis equipment as shown in Figure 1.

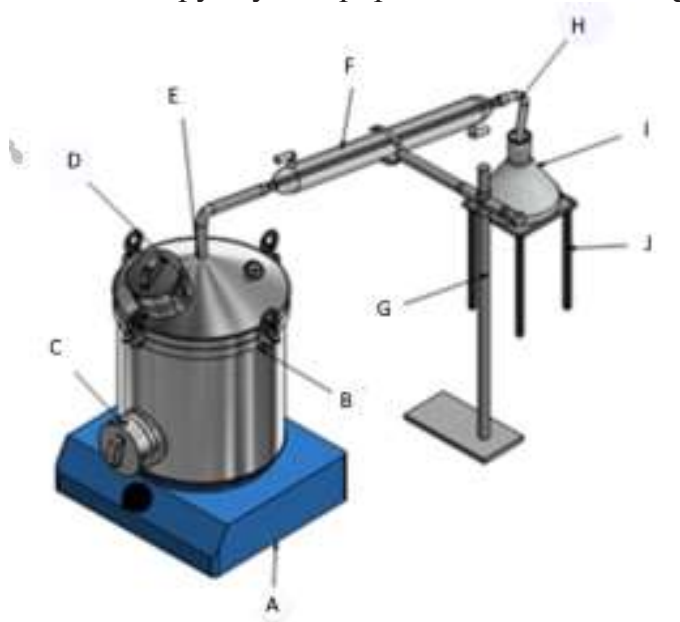

Fig. 1. Pyrolysis processing Stove A), Pyrolysis outlet hole B), Reactor C), Pyrolysis inlet hole D), Steam outlet E), Condenser F), Statip G), Adapter H), Erlenmeyer I), and Leg J). 


\subsubsection{Procedure}

The research was conducted through two stages of processing. The first step was the preparation of water hyacinth for chemical composition analysis in hemicellulose, cellulose and lignin. Chemical composition analysis used the Chasson Data Method. The second stage was the pyrolysis to determine the effect of temperature on the volume of liquid smoke. For the pyrolysis stage, water hyacinth was cut into pieces with a size of about $2 \mathrm{~cm}$ to $3 \mathrm{~cm}$ and then put the pyrolysator. Pour as much as $700 \mathrm{~g}$ of the dried water hyacinth into the 316 stainless steel pyrolysis reactor with a length of $360 \mathrm{~mm}$ and an internal diameter of $240 \mathrm{~mm}$ under atmospheric vacuum. The reactor was heated using a gas stove. Temperature variations were designed in $117{ }^{\circ} \mathrm{C}, 400{ }^{\circ} \mathrm{C}$ and $683{ }^{\circ} \mathrm{C}$. Furthermore, liquid smoke generated in the Erlenmeyer after passing through the condenser is accommodated as a result.

\section{Results and discussion}

The chemical composition of the water hyacinth Rawa pening, Semarang District, Indonesia shown in Figure 2 was hemicellulose, cellulose and lignin content as 36 \%, $21 \%$ and $7 \%$ dry weight, respectively. Figure 2 also depicts other materials, i.e. hardwood, softwood, coconut shell and cassava stems. Lignocellulose as biomass in the pyrolysis turns into charcoal, liquid smoke and fuel [5]. The chemical composition of water hyacinth has the highest hemicellulose content, while the smallest lignin when compared to the others such as softwood, hardwood, coconut shell, and cassava stems, This is inversely proportional to the coconut shell, where lignin is greater than hemicellulose. Hemicellulose pyrolysis containing pentosan and hexosan will produce furan and its derivatives and produce carboxylic acid as well as acetic acid. Pyrolysis of cellulose will produce acetic acid and homologous, water, furan and phenol. Lignin pyrolysis is an essential factor in providing smoke odor for smoked products. The resulting compounds are phenols and phenol esters $[6,7]$. These compounds in liquid smoke potentially a preservative.

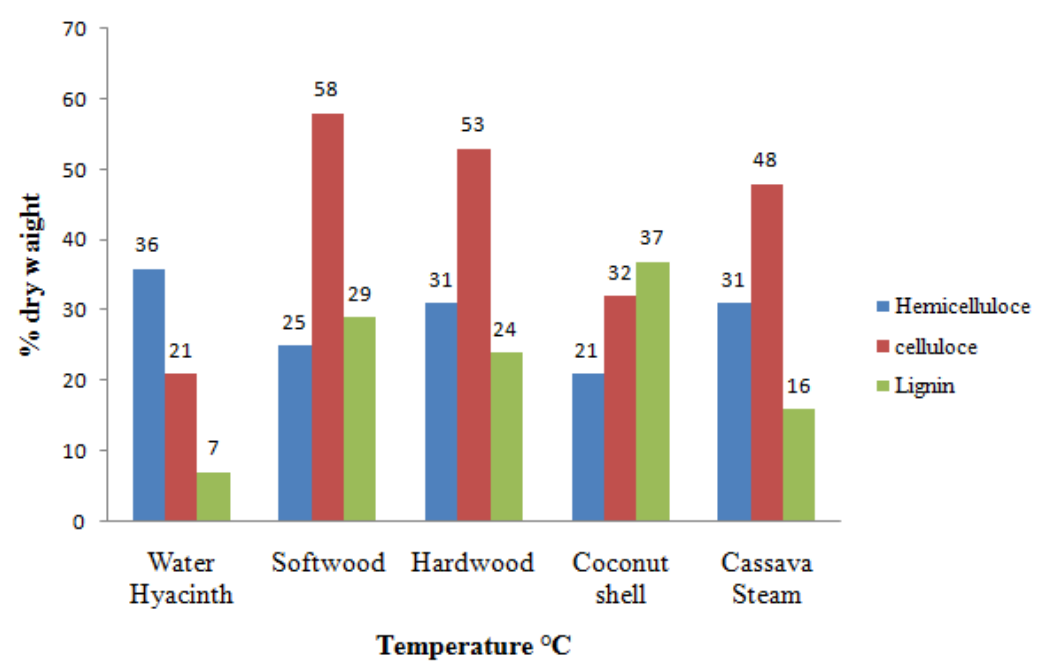

Fig. 2. Chemical Composition of water hyacinth and several other biomass

The temperature influence on the volume of liquid smoke, that the higher the temperature, the more liquid smoke produced. In Figure 3 the amount of liquid smoke produced is $0.2 \mathrm{~mL}$ per $100 \mathrm{~g}, 12.3 \mathrm{~mL}$ per $100 \mathrm{~g}, 6.3 \mathrm{~mL}$ per $100 \mathrm{~g}$ dried biomass for 
temperature $117{ }^{\circ} \mathrm{C}, 400{ }^{\circ} \mathrm{C}$, and $683{ }^{\circ} \mathrm{C}$ respectively. Hemicellulose pyrolysis occurs at temperatures of $200{ }^{\circ} \mathrm{C}$ to $250{ }^{\circ} \mathrm{C}, 280{ }^{\circ} \mathrm{C}$ to $320^{\circ} \mathrm{C}$ of cellulose pyrolysis and $400{ }^{\circ} \mathrm{C}$ for lignin pyrolysis [8]. So it can be underlined that the pyrolysis of water hyacinth at a temperature of $117^{\circ} \mathrm{C}$ is expected to occur decomposition of hemicellulose compounds. However, the decomposition of hemicellulose that starting at $200{ }^{\circ} \mathrm{C}$ has not been reached thus resulted less volume. But at $400{ }^{\circ} \mathrm{C}$ cellulose and lignin decomposed, resulting more volume of liquid smoke. According to Utomo et al. at $683{ }^{\circ} \mathrm{C}$ pyrolysis produced carbon monoxide, hydrogen, hydrocarbons and tar [8-10]. Therefore it need further research to find out the chemical compound content of the liquid smoke produced.

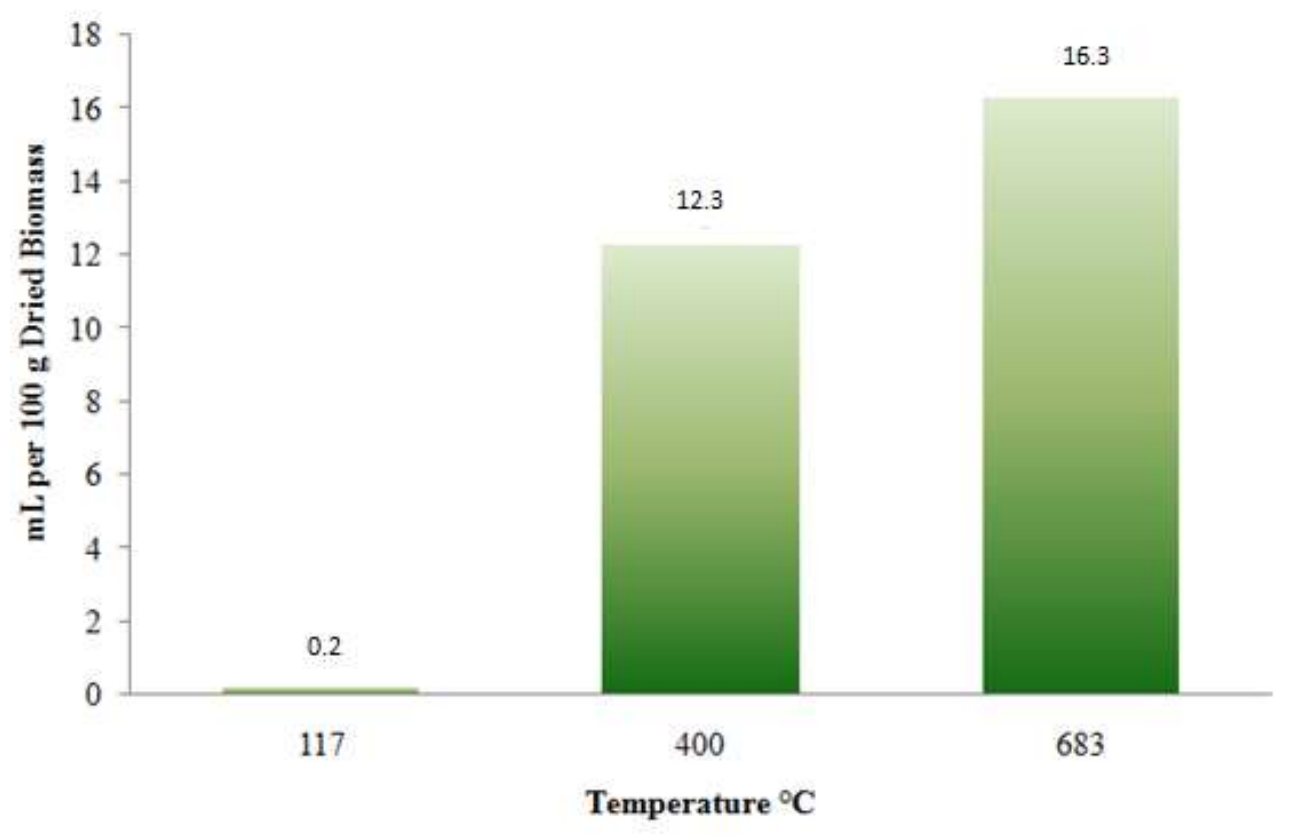

Fig. 3. Effect of Temperature on the volume of liquid smoke produced

\section{Conclusion}

The conclusion of this research is the effect of temperature was significant on liquid smoke products. It was proven that the higher the pyrolysis temperature, the greater the liquid smoke produced. The liquid smoke was obtained for $0.2 \mathrm{~mL}$ per $100 \mathrm{~g}, 12.3 \mathrm{~mL}$ per $100 \mathrm{~g}$ and $16.3 \mathrm{~mL}$ per $100 \mathrm{~g}$ dried biomass water hyacinth at a temperature of $117^{\circ} \mathrm{C}, 400{ }^{\circ} \mathrm{C}$ and $683{ }^{\circ} \mathrm{C}$, respectively

\section{References}

1. D.A. Wulandari, D. Kurniani, S. Edhisono, F. Ardianto, D. Dahlan. MATEC Web of Conferences, 270, 04018(2019). https://doi.org/10.1051/matecconf/201927004018

2. S. Sadaka, A.A. Boateng. Pyrolysis and Bio Oil. University of Arkansas Agriculture and Natural Resources. (2009).p.5.

https://scholar.google.co.id/scholar?hl=id\&as_sdt=0\%2C5\&q=2.\%09Sadaka $+\mathrm{S} \% 2 \mathrm{C}+$

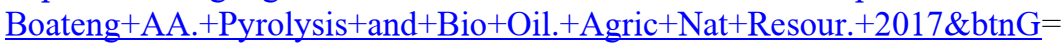


3. G. Ozbay, N. Ayrilmis. Effect of Pyrolysis Temperature On Bio-Oil Production From vacuum Pyrolysis of Waste From Wood Industry. Proceedings of 117th The IIER International Conference, Helsinki, Finland. 56-58(2017)

https://www.google.com/url?sa=t\&rct=j\&q=\&esrc=s\&source=web\&cd=\&cad=rja\&ua ct $=8 \& v e d=2$ ahUKEwi86NLDv-

jqAhXSbn0KHSWYBfkQFjAAegQIBBAB\&url=http $\% 3 \mathrm{~A} \% 2 \mathrm{~F} \% 2 \mathrm{Fwww}$.worldresear chlibrary.org\%2Fup_proc\%2Fpdf\%2F1015-150521687756-

58.pdf\&usg=AOvVaw3N3zaTEmrLxovQ4MQ8fYCD

4. T. Kan, V. Strezov, T.J. Evans, Renewable Sustainable Energy Reviews. 57:11261140(2016). doi:10.1016/j.rser.2015.12.185 https://www.sciencedirect.com/science/article/abs/pii/S1364032115015683

5. T. Dickerson, J. Soria, Energies. 6,1:514-538(2013). doi:10.3390/en6010514 or https://www.mdpi.com/1996-1073/6/1/514

6. R. Hadanu, D.A.N. Apituley, Makara Journal of Science. 20,3:95-100(2016). https://doi.org/10.7454/mss.v20i3.6239

7. G. Ozbay, A. Ozcifci, E.S. Kokten, Tirkish Journal og Agriculture and Forestry. 40:705-714(2016).

https://journals.tubitak.gov.tr/agriculture/abstract.htm?id=19386

8. M. Faisal, A.R. Yelviasunarti, H. Desvita, Rasayan Journal Chemistry. 11,2:871876(2018). DOI: 10.31788/RJC.2018.1123035

9. H. Ma, T. Li, S. Wu, X. Zhang, Bioresource Technology, 309,123351(2020). https://doi.org/10.1016/j.biortech.2020.123351

10. F. Swastawati, E. Susanto, B. Cahyono, W. Aji, APCBEE Procedia, 2:1-6(2012). https://doi.org/10.1016/j.apcbee.2012.06.001 